\title{
CONSTITUCIONALIZAÇÃO DO DIREITO CIVIL E APLICABILIDADE DOS DIREITOS FUNDAMENTAIS SOCIAIS ÀS RELAÇÕES PRIVADAS
}

\author{
SÉRGIO AUGUSTIN* \\ ÂNGELA ALMEIDA**
}

\begin{abstract}
RESUMO: O presente estudo aborda os principais problemas concernentes aos fundamentos e à extensão da incidência dos direitos fundamentais sociais nas relações privadas. Na primeira parte do texto, procurou-se situar historicamente o tema, identificando e explicando o conjunto de fatores que contribuíram para o surgimento do debate. Após, são expostas as principais formulações apresentadas no âmbito da doutrina constitucional. Em seguida, é examinado o tratamento jurisprudencial concedido ao problema. Por fim, procurou-se esboçar alguns critérios ético-jurídicos relativos à sindicabilidade dos direitos fundamentais sociais no campo privado, tomando-se por base o princípio da dignidade da pessoa humana e o da solidariedade.
\end{abstract}

PALAVRAS-CHAVES: Constitucionalização do Direito Civil; Direitos Fundamentais Sociais; Relações Privadas.

ABSTRACT: This study is about the main problems about fundamentals and the extension of the incidence of social fundamental rights on private relationships. At the first part of the study, it tried to historically explain it, identifying the set of factors that contributed to the emergence of the discussing. After that, it will be showed the major formulations presented over constitutional doctrine. Then, is examined the jurisprudential treatment given to the problem. At the end, it was to sketch some legal ethical criteria concerning the fundamental social rights in the private field, based on the principle of human dignity and solidarity.

KEYWORDS: Constitutionalisation of the Civil Law; Fundamental Social Rights, Private Relationships.

SUMÁRIO: Introdução; 1. Os antecedentes históricos da aplicabilidade dos direitos fundamentais socias às relações privadas; 2 . O debate doutrinário: 3 . A posição da jurisprudência brasileira; 4. A garantia do mínimo existencial; 5. O princípio da solidariedade; Conclusão; Referências.

SUMMARY: Introduction; 1 . The historical antecedents of the applicability of fundamental social rights to private relationships; 2 . The doctrinal debate; 3 . The position of Brazilian jurisprudence; 4. The warranty of minimum to live; 5 . The principle of solidarity; Conclusion; References.

Artigo recebido em 8.10.2010. Pareceres emitidos em 13.12.2010 e 18.12.2010.

Artigo aceito para publicação em 6.01.2011.

* Doutor em Direito pela Universidade Federal do Paraná. Coordenador do Mestrado em Direito da Universidade de Caxias do Sul. Juiz de Direito.

${ }^{* *}$ Mestre em Direito pela Universidade de Caxias do Sul. Analista Tributária da Receita Federal do Brasil. 


\section{INTRODUÇÃO}

Já não é mais novidade afirmar que a Constituição figura hoje no centro do sistema jurídico, de onde irradia sua força normativa, dotada de supremacia formal e material. É nesse ambiente que se dá a virada axiológica do direito civil, tanto pela vinda de suas normas para a Constituição como, sobretudo, pela ida da Constituição para a interpretação do direito civil, tornando tênues as fronteiras entre o direito público e o privado. ${ }^{1}$

Se no século XIX, na Europa, o Código Civil desempenhara, em caráter exclusivo, a função de normatizar as relações jurídicas entre os particulares - ocupando, assim, posição central no sistema de fontes ${ }^{2}$ - a partir do segundo pós-guerra a Constituição passa a ser o elemento que confere ordem, unidade e harmonia ao sistema jurídico, impondo um novo conjunto de valores e princípios, que incluem: (i) a função social da propriedade e do contrato; (ii) a proteção do consumidor, com o reconhecimento de sua vulnerabilidade; (iii) a igualdade entre os cônjuges; (iv) a igualdade entre os filhos; (v) a boa-fé objetiva; (vi) o equilíbrio contratual. ${ }^{3}$

A Constituição, hoje, é a fonte reguladora tanto do poder político como da sociedade civil. Como afirma Konrad Hesse, ela "no es más sólo el orden jurídico fundamental del Estado", tendo se tornado "el orden jurídico fundamental de la Comunidad”, pois suas "normas también incluyen - con bastante claridad garantías, tales como el matrimonio, la familia, la propiedad, la educación o la libertad del arte y la ciencia - las bases de la organización de la vida no estatal". ${ }^{4}$ Nessa perspectiva, não há mais limites precisos que separam o direito constitucional do direito privado, não sendo possível concebê-los como "compartimientos estancos, como mundos separados, impermeables, regido por lógicas diferentes". 5

Superada a ideia de que o direito constitucional e o direito privado tinham campos de incidência diversos, emerge o problema da aplicabilidade dos direitos fundamentais às relações privadas e, mais particularmente, dos direitos sociais e econômicos que, por sua natureza, vinculam em primeira linha os poderes estatais, tais como os direitos à saúde, à educação e à moradia, previstos no art. $6^{\circ}$ da Constituição Federal.

\footnotetext{
${ }^{1}$ Sobre as relações entre o direito público e o direito privado, cf. HESSE, Konrad. Derecho constitucional y derecho privado. Madrid: Civitas, 2001.

2 Sobre a Constituição como o ápice do sistema de fontes, cf. OTTO, Ignacio de. Derecho constitucional: sistema de fuentes. Barcelona: Ariel, 1999, p. 17. Para este autor: "lo que define las normas constitucionales no es su objeto, pero la posición que ocupan en el sistema jurídico. La Constitución se puede definir así como el conjunto de normas que regulan la creación de normas por parte de los órganos superiores del Estado".

${ }^{3}$ BARROSO, Luís Roberto. A constitucionalização do direito civil e o direito civil. In: TEPEDINO, Gustavo (Org.). Direito civil contemporâneo: novos problemas à luz da legalidade constitucional: anais do Congresso Internacional de Direito Civil-Constitucional da Cidade do Rio de Janeiro. São Paulo: Atlas, 2008, p. 238-61, p. 258.

${ }^{4}$ HESSE, Konrad. Escritos de derecho constitucional. 2. ed. Madrid: Centro de Estudios Políticos y Constitucionales, 1992, p. 16

${ }^{5}$ BILBAO Ubillos, Juna María. La eficacia de los derechos fundamentales frente a particulares: análisis de la jurisprudencia del Tribunal Constitucional. Madrid: Centro de Estudios Políticos y Constitucionales, 1997, p. 258.
} 
As maiores dificuldades concernentes ao reconhecimento de uma eficácia dos direitos fundamentais sociais nas relações inter privatos dizem respeito à sua dimensão prestacional. Em quais circunstâncias pode alguém, por exemplo, exigir que um particular lhe custeie um tratamento de saúde, ou lhe proporcione o acesso à educação? Esta é uma questão complexa, tanto que o senso comum, em um primeiro momento, parece nos inclinar a uma resposta negativa. ${ }^{6}$

Apesar de que o próprio texto constitucional brasileiro acena, em diversas passagens, no sentido da co-responsabilidade dos particulares em relação à garantia dos direitos fundamentais sociais. No art. 194, o constituinte estabeleceu que "a seguridade social compreende um conjunto integrado de ações de iniciativa dos Poderes Públicos e da sociedade destinadas a assegurar os direitos relativos à saúde, à previdência, e à assistência social”. Já o art. 205 da Constituição Federal dispõe que a educação "é um direito de todos e dever do Estado e da família”, determinando que ela deva ser "promovida e incentivada com a colaboração da sociedade”. Neste mesmo diapasão, o art. 227 da Lei Maior atribuiu não só ao Estado, mas também “à família e à sociedade” o dever de assegurar à criança e ao adolescente o gozo dos seus direitos fundamentais, o mesmo ocorrendo em relação às pessoas idosas (CF, art. 230). Por fim, em passagem ainda mais clara, o texto constitucional consagrou a eficácia horizontal direta do direito à moradia, ao prever duas hipóteses de usucapião constitucional com prazos menores (CF, arts. 183 e 191), restringindo com isso o direito individual de propriedade de terceiros em proveito de um direito fundamental social. Mesmo assim, no Brasil, o debate sobre esse tema começa a ganhar espaço muito recentemente, o que, aliás, ocorre em um contexto de progressivo incremento na produção acadêmica sobre direitos fundamentais sociais. ${ }^{7}$

Neste estudo, pretende-se abordar os principais problemas concernentes aos fundamentos e à extensão da incidência dos direitos fundamentais sociais nas relações privadas. Na primeira parte do texto, procurar-se-á situar histórica e teoricamente o tema, identificando e explicando o conjunto de fatores que contribuíram para o surgimento do debate. Após, serão expostas as principais formulações apresentadas no âmbito da doutrina constitucional nacional e comparada. Em seguida, será examinado o tratamento que a jurisprudência brasileira concede ao problema. Por fim, procurar-se-á esboçar alguns critérios ético-jurídicos relativos à sindicabilidade dos direitos fundamentais sociais no campo privado, tomando-se por base o princípio da dignidade da pessoa humana e o da solidariedade.

1. OS ANTECEDENTES HISTÓRICOS DA APLICABILIDADE DOS DIREITOS FUNDAMENTAIS SOCIAIS ÀS RELAÇÕES PRIVADAS

O direito constitucional e o direito civil atravessaram, nos dois últimos séculos, etapas que se distinguem pela indiferença ou pela convivência intensa entre eles.

\footnotetext{
${ }^{6}$ SARMENTO, Daniel. Direitos Fundamentais e Relações Privadas. 2. ed. Rio de Janeiro: Lumen Juris, 2008, p. 294.

${ }^{7}$ SARLET, Ingo Wolfgang. Direitos fundamentais sociais, "mínimo existencial” e direito privado: breves notas sobre alguns aspectos da possível eficácia dos direitos sociais nas relações entre particulares. In: SARMENTO, Daniel; GALDINO, Flávio (Organizadores). Direitos fundamentais: estudos em homenagem ao Professor Ricardo Lobo Torres. Rio de Janeiro: Renovar, 2006a, p. 551-602, p. 556.
} 
O marco inicial dessa trajetória é a Revolução Francesa, que deu a cada um desses ramos do Direito o seu objeto de trabalho: ao direito constitucional, uma Constituição, promulgada em 1791; ao direito civil, o Código Civil napoleônico, de 1804. Apesar da contemporaneidade dos dois documentos, direito constitucional e direito civil não se integravam nem se comunicavam entre si. Cada um cumpria seu papel: a Constituição, o de limitar o Estado e o poder político; o Código Civil, o de assegurar o mais amplo espaço de autonomia aos indivíduos, nomeadamente no campo econômico. O ideário liberal-burguês triunfante da Revolução Francesa tinha cindido a ordem política do citoyen, de um lado, e a ordem privada do bourgeois - protegendo seus negócios com o Código Civil - de outro lado. ${ }^{8}$

Para os pensadores iluministas, a plenitude da pessoa dava-se com o domínio sobre as coisas, com o ser proprietário. A liberdade dos modernos, ao contrário dos antigos, ${ }^{9}$ é concebida como não-impedimento. Livre é quem pode deter, gozar e dispor de seus bens, sem impedimentos, salvo os ditados pela ordem pública e os bons costumes, sem interferência do Estado. As primeiras constituições, portanto, nada regularam sobre as relações privadas, cumprindo sua função de delimitação do Estado e do poder político. Ao Estado coube apenas estabelecer as regras do jogo das liberdades privadas, no plano infraconstitucional, de sujeitos de direitos formalmente iguais, abstraídos de suas desigualdades reais.

Como legado do Estado liberal, a liberdade e a igualdade jurídicas, apesar de formais, incorporaram-se ao catálogo de direitos das pessoas humanas, e não apenas dos sujeitos das relações jurídicas, e nenhuma ordem jurídica democrática pode delas abrir mão. Os códigos cristalizaram a igualdade formal de direitos subjetivos, rompendo a estrutura estamental fundada no jus privilegium, nos locais reservados às pessoas em razão de suas origens. ${ }^{10}$ Mas, como a dura lição da história demonstrou, as codificações liberais também serviram de instrumento de hegemonia dos mais fortes, sem qualquer espaço para a justiça social, gerando reações e conflitos que redundaram no advento do Estado social. ${ }^{11}$

Ao longo do século XX, com o advento do Estado social e a percepção crítica da desigualdade material entre os indivíduos, o direito civil começa a superar o individualismo exacerbado, deixando de ser o reino soberano da autonomia da vontade. Em nome da solidariedade social e da função social de instituições como a propriedade e o contrato, o Estado começa a interferir nas relações entre particulares, mediante a introdução de normas de ordem pública. Tais normas se destinam, sobretudo,

\footnotetext{
${ }^{8}$ BARROSO, op. cit., p. 257.

${ }^{9}$ Como se sabe Benjamin Constant, em célebre ensaio, afirmou que a noção democrática de liberdades estaria ultrapassada, pois corresponderia à "liberdade dos antigos”, da polis grega. Para ele, a liberdade moderna seria a liberdade negativa dos liberais, equivalente à proteção da esfera privada do indivíduo diante dos tentáculos do poder estatal. CONSTANT, Benjamin. De la liberté des anciens compare a celle des modernes, Paris, 1819. Disponível no sítio: <http://www.panarchy.org/constant/liberte.1819.html>. Acesso em: 22 set. 2010.

${ }^{10}$ LÔBO, Paulo Luiz Netto. Constitucionalização do direito civil. Revista de Informação Legislativa, Brasília, 1999, a. 36, n. 141, p. 99-109, jan./mar.

${ }^{11}$ BARROSO, op. cit., p. 257-8.
} 
à proteção do lado mais fraco da relação jurídica, como o consumidor, o locatário e o empregado. É a fase do dirigismo contratual, que consolida a publicização do direito privado. $^{12}$

Com isso, muitos propugnam pela superação da velha dicotomia público/privado, que resiste à falta de outra mais convincente e mantém sua utilidade no plano didático. Porém, vale ressaltar que o fato de haver mais ou menos normas cogentes não elimina a natureza originária da relação jurídica privada, vale dizer, da relação que se dá entre titulares de direito formalmente iguais. Por outras palavras, não é o grau de intervenção legislativa, ou de controle do espaço privado, que gera a natureza de direito público. Como afirma Paulo Netto Lôbo: "independentemente do grau de intervenção estatal, se o exercício do direito se dá por particular em face de outro particular, ou quando o Estado se relaciona paritariamente com o particular, sem se valer de seu império, então o direito é privado". ${ }^{13}$

Para muitos, a publicização também teria o mesmo significado de constitucionalização. Todavia, são situações diferentes. A denominada publicização deve ser entendida como o processo de intervenção legislativa infraconstitucional, característica do Estado social do século XX, ao passo que a constitucionalização tem por fito submeter o direito privado aos fundamentos de validade constitucionalmente estabelecidos. ${ }^{14}$

Veja-se que o direito de família, especialmente, passa por uma revolução, com o destaque para a afetividade em prejuízo de concepções puramente formais ou patrimoniais. Há, hoje, o reconhecimento de uma pluralidade de formas de constituição da família: casamento, união estável, famílias monoparentais, união homoafetiva. Não é o caso de se percorrerem as múltiplas situações de impacto dos valores constitucionais sobre o direito civil, especificamente, e sobre o direito privado em geral. ${ }^{15}$ Mas há dois desenvolvimentos que merecem destaque, por sua relação com o tema aqui desenvolvido.

O primeiro deles diz respeito ao princípio da dignidade da pessoa humana na dogmática constitucional. Após o término da Segunda Guerra Mundial, tem início a

\footnotetext{
${ }^{12}$ Sobre o Estado social, confira-se: "O Estado social, no plano do direito, é todo aquele que tem incluída na Constituição a regulação da ordem econômica e social. Além da limitação ao poder político, limita-se o poder econômico e projeta-se para além dos indivíduos a tutela dos direitos, incluindo o trabalho, a educação, a cultura, a saúde, a seguridade social, o meio ambiente, todos com inegáveis reflexos nas dimensões materiais do direito civil”. Ibidem, p. 102.

${ }^{13}$ Ibidem, p. 101.

${ }^{14}$ A locução constitucionalização do direito é de uso relativamente recente na terminologia jurídica e, além disso, comporta múltilos sentidos: (i) por ela se poderia pretender caracterizar qualquer ordenamento jurídico no qual vigorasse uma Constituição dotada de supremacia (traço comum de grande número de sistemas jurídicos contemporâneos); (ii) poderia ela servir para identificar o fato de a Constituição formal incorporar em seu texto inúmeros temas afetos aos ramos infraconstitucionais do direito (fenômeno verificado na Constituição portuguesa de 1976, espanhola de 1978 e brasileira de 1988); e (iii) poderia estar associada a um efeito expansivo das normas constitucionais, cujo conteúdo material e axiológico se irradia, com força normativa, por todo o sistema jurídico. Cf. BARROSO, op. cit., p. 244.

${ }^{15}$ Para este fim, cf. TEPEDINO, Gustavo (Coord.). Problemas de direito civil-constitucional. Rio de Janeiro: Renovar, 2000. Trata-se de obra coletiva na qual se discute a constitucionalização do direito civil em domínios diversos, incluindo o direito das obrigações, as relações de consumo, o direito de propriedade e o direito de família.
} 
reconstrução dos direitos humanos, ${ }^{16}$ que se irradiam a partir da dignidade da pessoa humana, ${ }^{17}$ referência que passou a constar dos documentos internacionais e das Constituições democráticas, ${ }^{18}$ tendo figurado na Carta brasileira de 1988 como um dos fundamentos da República (art. $1^{\circ}$, III). A dignidade humana impõe limites e atuações positivas ao Estado e à sociedade, no atendimento das condições mínimas de uma existência digna, ${ }^{19}$ expressando-se em diferentes dimensões. ${ }^{20}$ No tema específico aqui versado, o princípio promove uma despatrimonialização ${ }^{21}$ e uma repersonalização ${ }^{22}$ do direito civil, com ênfase em valores existenciais e do espírito, bem como no reconhecimento e desenvolvimento dos direitos da personalidade, tanto em sua dimensão física quanto psíquica. ${ }^{23}$

O segundo desenvolvimento doutrinário que comporta uma nota especial é a aplicabilidade dos direitos fundamentais às relações privadas. ${ }^{24} \mathrm{O}$ debate remonta à decisão do caso $L u ̈ h^{25}$, que superou a rigidez da dualidade público/privado ao

${ }^{16}$ Cf. LAFER, Celso. A reconstrução dos direitos humanos: um diálogo com o pensamento de Hannah Arendt. São Paulo: Companhia das Letras, c1988. Cf. tb. CANÇADO TRINDADE, Antônio Augusto. Elementos fundamentais da evolução da proteção internacional dos direitos humanos. Arquivos do Ministério da Justiça, v. 177, 1991, p. 39-60.

${ }^{17}$ Vejam-se dois excertos representativos do entendimento dominante: ANDRADE, José Carlos Vieira de. Os direitos fundamentais na Constituição portuguesa de 1976. Coimbra: Almedina, 1998, p. 102: “[O] princípio da dignidade da pessoa humana está na base de todos os direitos constitucionalmente consagrados, quer dos direitos e liberdades tradicionais, quer dos direitos de participação política, quer dos direitos dos trabalhadores e dos direitos a prestações sociais”; SARMENTO, Daniel. A ponderação de interesses na Constituição Federal. Rio de Janeiro: Lumen Juris, 2003, p. 59-60: "O princípio da dignidade da pessoa humana representa o epicentro axiológico da ordem constitucional, irradiando efeitos sobre todo o ordenamento jurídico e balizando não apenas os atos estatais, mas também toda a miríade de relações privadas que se desenvolvem no seio da sociedade civil e do mercado”.

${ }^{18}$ Como, e.g., na Constituição italiana de 1947, na Declaração Universal dos Direitos Humanos de 1948, na Constituição alemã de 1949, na Constituição portuguesa de 1976, na Constituição espanhola de 1978.

${ }^{19}$ Sobre o tema, v. BARCELLOS, Ana Paula de. A eficácia jurídica dos princípios constitucionais: o princípio da dignidade da pessoa humana. Rio de Janeiro: Renovar, 2002, p. 305: "O conteúdo básico, o núcleo essencial do princípio da dignidade da pessoa humana, é composto pelo mínimo existencial, que consiste em um conjunto de prestações materiais mínimas sem as quais se poderá afirmar que o indivíduo se encontra em situação de indignidade”.

${ }^{20}$ Em denso estudo, Maria Celina Bodin de Moraes decompõem o conteúdo jurídico da dignidade humana em quatro princípios: igualdade, integridade física e moral (psicofísica), liberdade e solidariedade. Cf. MORAES, Maria Celina Bodin de. Conceito de dignidade humana: substrato axiológico e conteúdo normativo. In: SARLET, Ingo Wolfgang (Org.). Constituição, Direitos Fundamentais e Direito Privado. 2. ed. rev. e ampl. Porto Alegre: Livraria do Advogado, 2006b, p. 107-149.

${ }^{21}$ PERLINGIERI, Pietro. Perfis do direito civil: introdução ao direito civil constitucional. Rio de Janeiro: Renovar, 1997, p. 33.

${ }^{22}$ FACHIN, Luiz Edson; RUZYK, Carlos Eduardo Pianovski. Um projeto de Código Civil na contramão da Constituição. Revista Trimestral de Direito Civil, Rio de Janeiro, v. 1, n. 4, p. 243-264, 2000, p. 243 : "[A] aferição da constitucionalidade de um diploma legal, diante da repersonalização imposta a partir de 1988, deve levar em consideração a prevalência da proteção da dignidade humana em relação às relações jurídicas patrimoniais”.

${ }^{23}$ Sobre a tutela da integridade psicofísica, cf. PERLINGIERI, Pietro. O Direito Civil na Legalidade Constitucional. Rio de Janeiro: Renovar, 2008, p. 776-77.

${ }^{24}$ Para uma perspectiva de direito comparado da relação entre direitos fundamentais e direito privado, cf. MONTEIRO, António Pinto; NEUNER, Jörg; SARLET, Ingo Wolfgang (Orgs.). Direitos fundamentais e direito privado: uma perspectiva de direito comparado. Coimbra: Almedina, setembro 2007.

${ }^{25}$ Os fatos subjacentes eram os seguintes: Erich Lüth, presidente do Clube de Imprensa de Hamburgo, incitava o 
admitir a aplicação da Constituição às relações particulares, inicialmente regidas pelo Código Civil. ${ }^{26}$ A partir daí, há razoável consenso doutrinário de que os direitos fundamentais individuais se aplicam, em alguma medida, às relações privadas. A divergência reside na determinação do modo e da intensidade dessa incidência, bem como na aplicabilidade dos direitos fundamentais sociais. A seguir, vejam-se os argumentos esgrimidos na literatura.

\section{O DEBATE DOUTRINÁRIO}

No Brasil, Ingo Sarlet foi o primeiro a se manifestar conclusivamente pela eficácia direta dos direitos fundamentais sociais nas relações entre particulares, asseverando que todos os direitos fundamentais (mesmo os denominados direitos a prestações em sentido estrito) são eficazes no âmbito das relações privadas, inexistindo, em princípio, distinção entre os direitos de defesa e os prestacionais, em que pesem os objetos diversos e a circunstância de que os direitos fundamentais do último grupo possam até vincular, na condição de obrigado em primeira ordem, os órgãos estatais. ${ }^{27}$ Em posteriores estudos específicos sobre os direitos fundamentais à saúde ${ }^{28}$ e à moradia, ${ }^{29}$ o constitucionalista voltou a insistir que, em ambos os casos, é possível vislumbrar uma eficácia horizontal. Contudo, foi em estudo mais recente que Sarlet desenvolveu detidamente suas ideias sobre o assunto, sempre no sentido da eficácia direta dos direitos sociais no âmbito das relações entre particulares. Nesse novo estudo, o autor desenvolveu o aspecto da ponderação entre o direito fundamental social e a autonomia privada, destacando, dentre outros fatores, a importância da proteção ao mínimo existencial, que, também, em sua opinião, vincula diretamente os atores privados. $^{30}$

Tal posição foi compartilhada, desenvolvida e reforçada por Daniel Sarmento, com apoio no princípio da solidariedade, que, à evidência, não vincula apenas os órgãos estatais, mas a sociedade como um todo. Segundo Sarmento, existe uma série de razões que justifica, hoje, a concepção de que, ao lado do dever primário do

boicote de um filme dirigido por Veit Harlan, cineasta que havia sido ligado ao regime nazista no passado. A produtora e a distribuidora do filme obtiveram, na jurisdição ordinária, decisão determinando a cessação de tal conduta, por considerá-la em violação do § 826 do Código Civil (BGB): “Quem, de forma atentatória aos bons costumes, infligir dano a outrem, está obrigado a reparar os danos causados”. O Tribunal Constitucional Federal reformou a decisão, em nome do direito fundamental à liberdade de expressão, que deveria pautar a interpretação do Código Civil.

${ }^{26}$ Esta decisão (BverfGE 7, 198) é comentada por inúmeros autores nacionais, dentre os quais: MENDES, Gilmar Ferreira. Direitos fundamentais e controle de constitucionalidade: estudos de direito constitucional. 2. ed. rev. e ampl. São Paulo: Celso Bastos, 1999; PEREIRA, Jane Reis Gonçalves. Interpretação constitucional e direitos fundamentais. Rio de Janeiro: Renovar, 2006.

${ }^{27}$ SARLET, Ingo Wolfgang. Direitos fundamentais e direito privado: algumas considerações em torno da vinculação dos particulares aos direitos fundamentais. In: SARLET, Ingo Wolfgang (Org.). A Constituição concretizada: construindo pontes com o público e o privado. Porto Alegre: Livraria do Advogado, 2000, p. 154.

${ }_{28}$ SARLET, Ingo Wolfgang. Algumas considerações em torno do conteúdo, eficácia e efetividade do direito à saúde na Constituição de1988. Revista Interesse Público, São Paulo, 2001, v. 3, n. 12, p. 91-107, out./dez.

${ }^{29}$ SARLET, Ingo Wolfgang. O direito fundamental à moradia na Constituição: algumas anotações a respeito de seu contexto, conteúdo e possível eficácia. In: MELLO, Celso D. de Albuquerque; TORRES, Ricardo Lobo (Diretores). Arquivos de Direitos Humanos. Rio de Janeiro: Renovar, 2002, v. 04, p. 63-115. ${ }^{30}$ SARLET, 2006a, op. cit., p. 551-602. 
Estado, de garantir os direitos sociais, é possível também visualizar um dever secundário da sociedade de assegurá-los. ${ }^{31}$

Essa mesma posição favorável à eficácia direta pode ser inferida da lição de Gustavo Tepedino, quando, ao referir-se à abertura da "cláusula geral de tutela e promoção da pessoa humana”, deixa transparecer que esta envolve a tutela de direitos sociais, como a saúde. ${ }^{32}$ Idêntico entendimento foi abraçado, na doutrina italiana, por Pietro Perlingieri. O jurista italiano manifesta-se de forma inequívoca a favor da eficácia imediata dos direitos fundamentais sociais nas relações privadas, afirmando que “[...] a norma constitucional pode também sozinha (quando não existirem normas ordinárias que disciplinem a fattispecie em consideração) ser a fonte da disciplina de uma relação de direito civil”. 33

Na doutrina espanhola, Rafael de Asís suscita a questão se, além de obrigações negativas, os particulares, ante os direitos fundamentais, têm também obrigações positivas. De um lado, esse autor reconhece as dificuldades que a questão suscita, porque estão em jogo os direitos fundamentais individuais, à medida que obrigações positivas poderiam colidir com o valor da liberdade. De outro, questiona se a extensão de obrigações positivas a determinados grupos privados cuja relevância no ordenamento jurídico é evidente, não favoreceria e facilitaria o exercício de direitos e liberdades. Em seguida, pondera: "enfrentaríamos así con un problema de colisión de derechos, que, por otro lado, es ya clásico y pueden encontrarse mecanismos para su solución”. ${ }^{34}$ Além disso, Asís argumenta a favor da incidência de determinadas obrigações positivas ou de fazer, cujo significado seja a promoção de direitos fundamentais, e cujos titulares não sejam os poderes públicos tradicionais, "sino ciertos poderes de indudable relevancia social". ${ }^{35}$ Ao final e como conclusão, o jurista espanhol afirma que as dificuldades com a imposição de obrigações positivas a um sujeito, ou a um grupo, podem "ser retomadas en consideración, a través de la figura de la colisión de derechos, y a través de la adopción de soluciones en cada posible problema que pueda suscitarse". ${ }^{36}$

Canotilho, no entanto, parece preferir a tese da eficácia mediata dos direitos sociais sobre as relações privadas, ao contrário do que sustentara em relação aos direitos individuais, nomeados na ordem constitucional lusitana como "direitos, liberdades e garantias”. O jurista português aparentemente empresta a ela a sua adesão, ao somente consignar que a doutrina não tem dúvidas em aceitar a eficácia horizontal

\footnotetext{
${ }^{31}$ SARMENTO, 2008, op. cit., p. 295.

${ }^{32}$ TEPEDINO, Gustavo. Temas de Direito Civil. Rio de Janeiro: Renovar, 1999, p. 47-48.

${ }^{33}$ Ao criticar a teoria da eficácia mediata dos direitos fundamentais nas relações entre particulares, prevalecente na Alemanha, Perlingieri observa que: “[...] a normativa constitucional não deve ser considerada sempre e somente como mera regra hermenêutica, mas também como norma de comportamento, idônea a incidir sobre o conteúdo das relações entre situações subjetivas, funcionalizando-as aos novos valores”. Cf. PERLINGIERI, Pietro. Perfis do direito civil: introdução ao direito civil constitucional. Rio de Janeiro: Renovar, 1997, p. 11-12.

${ }^{34}$ ASÍS, Rafael de. Las paradojas de los derechos fundamentales como limites al poder. Madrid: Dykinson, 2000, p. 94

${ }^{35}$ Idem.

${ }^{36}$ Idem.
} 
dos direitos sociais sob duas modalidades de efeito mediato ou eficácia indireta: (i) impondo ao legislador a edição das normas sociais segundo os direitos constitucionais sociais e (ii) obrigando o intérprete a uma interpretação conforme as normas constitucionais sociais. $^{37}$

Postura ainda mais reticente é assumida, na doutrina espanhola, por Juan María Bilbao Ubillos, ao consignar que existem alguns direitos que "[...] por su propia naturaleza, son oponibles únicamente frente al Estado", 38 muito embora reconheça que a imposição expressa de limites aos poderes públicos não prova que os direitos fundamentais tenham eficácia unicamente contra o Estado. Ao final e como conclusão, Ubillos argumenta: "De todos modos, el juicio definitivo deberá hacerse em concreto, en el seno de una determinada relación, y atendiendo a las circunstancias del caso" ${ }^{39}$

Também para Quadra-Salcedo há direitos fundamentais a prestações (e.g. educação e trabalho) cujo único sujeito obrigado é o Estado e que, por isso, não podem ser exigidos dos particulares. Contudo, pondera esse autor, isso não implica que os particulares, sob qualquer aspecto, estão necessariamente desobrigados diante de direitos fundamentais a prestações. O particular não está na mesma posição do Estado, o que, de resto, não significa que não esteja obrigado a não interferir no desenvolvimento e na efetivação de um direito a prestações. ${ }^{40}$

Já o constitucionalista colombiano Rodolfo Arango, em sua tese de doutoramento, defendida na universidade alemã de Kiel, sob a orientação de Robert Alexy, manifestou-se contrariamente à eficácia horizontal direta dos direitos sociais, sem ao menos aludir à possibilidade do reconhecimento de efeito meramente mediato. Para ele, afora as exceções estabelecidas pelas próprias constituições, deve-se entender que os ônus equivalentes aos direitos sociais recaem sobre toda a sociedade, devendo, por isso mesmo, serem suportados pelo Estado, e não por qualquer agente privado ou particular. A vinculação direta dos particulares aos direitos sociais, em sua opinião, geraria problemas insolúveis, relativos à forma de determinação do círculo dos obrigados e ao alcance das respectivas obrigações em cada caso, já que não é possível conceber cada indivíduo como devedor de prestações sociais em relação a todos os outros. ${ }^{41}$

Wilson Steinmetz, no Brasil, também se posicionou contrariamente à atribuição de eficácia interprivada aos direitos sociais prestacionais. O constitucionalista gaúcho argumenta que, por definição, os particulares não estão vinculados aos direitos fundamentais do art. $6^{\circ}$ da CF. Na esteira de Alexy, Steinmetz define esses direitos como “direitos do indivíduo ante ao Estado a algo que - se o indivíduo possuísse meios suficientes e encontrasse no mercado oferta suficiente - poderia obter também

${ }^{37}$ CANOTILHO, José Joaquim Gomes. Direito Constitucional e Teoria da Constituição. 4. ed. Coimbra: Almedina, 2000. p. 441.

${ }^{38}$ BILBAO UBILLOS, Juan María. ¿En qué medida vinculan a los particulares los derechos fundamentales? In: SARLET, 2006b, op. cit., p. 301-339, p. 328.

${ }^{39}$ Ibidem, p. 329.

${ }^{40}$ QUADRA-SALCEDO, Tomás. El recurso de amparo y los derechos fundamentales en las relaciones entre particulares. Madrid: Civitas, 1981, p. 73-74.

${ }^{41}$ ARANGO, Rodolfo. El concepto de derechos sociales fundamentales. Bogotá: Legis, 2005, p. 102-107. 
de particulares”. ${ }^{42}$ Além disso, para ele, a imposição aos particulares de deveres correlatos aos direitos sociais colidiria como "o princípio da livre iniciativa (CF, $1^{\text {o }}$, IV, e art. 170, caput) - e, portanto, com a economia de mercado -, com os direitos fundamentais de liberdade e de propriedade (CF, art. 50, caput e XXII) e com o princípio da autonomia privada”. ${ }^{4}$ Steinmetz também discorda do reconhecimento de uma eficácia horizontal de direitos sociais em relação a certos particulares, mesmo em casos em que o próprio texto constitucional a menciona - por entender que, como a garantia desses direitos depende da disponibilidade de recursos materiais, a pobreza de milhões de famílias tornaria inviável a sua exigibilidade. ${ }^{44}$

No entanto, não só o texto constitucional brasileiro menciona a co-responsabilidade dos particulares em relação à garantia dos direitos fundamentais sociais como também a jurisprudência brasileira registra alguns exemplos importantes nesse sentido, especialmente em relação ao direito fundamental à saúde, citado por Steinmetz. ${ }^{45}$ Veja-se o tratamento jurisprudencial dispensado a esse tema.

\section{A POSIÇÃO DA JURISPRUDÊNCIA BRASILEIRA}

$\mathrm{Na}$ jurisprudência brasileira, há inúmeras decisões que utilizam o direito fundamental à saúde como vetor interpretativo para aplicação do conceito legal de cláusula abusiva, previsto no Código do Consumidor, com o fito de obrigar planos de saúde à realização de tratamentos médicos em casos de doenças excluídas por ajuste contratual, ou para invalidar limitações contratuais ao prazo de internação hospitalar dos pacientes. Vale destacar, nesse sentido, o acórdão proferido pela $3^{\mathrm{a}}$ Turma do STJ no Recurso Especial n. 158.728, relatado pelo Min. Carlos Alberto Direito, apreciado em 15 de maio de 1999:

PLANO DE SAÚDE - LIMITE TEMPORAL DE INTERNAÇÃO CLÁUSULA ABUSIVA - É abusiva a cláusula que limita no tempo a internação do segurado, o qual prorroga a sua presença em unidade de tratamento intensivo ou é novamente internado em decorrência do mesmo fato médico, fruto de complicações da doença, coberto pelo plano de saúde. O consumidor não é senhor do prazo de sua recuperação, que, como é curial, depende de muitos fatores, que nem mesmo os médicos são capazes de controlar. Se a enfermidade está coberta pelo seguro, não é possível, sob pena de grave abuso, impor ao segurado que se retire da unidade de tratamento intensivo, com o risco severo de morte, porque está fora do limite temporal estabelecido em uma determinada cláusula. Não pode a estipulação contratual ofender o princípio da razoabilidade, e se o faz, comete abusividade vedada pelo art. 51, IV, do Código de Defesa do Consumidor. Anote-se que a regra protetiva, expressamente, refere-se a uma desvantagem exagerada do consumidor e, ainda, a obrigações incompatíveis com a boa-fé e a eqüidade. ${ }^{46}$

${ }^{42}$ STEINMETZ, Wilson. A Vinculação dos Particulares a Direitos Fundamentais. São Paulo: Malheiros, 2004, p. 276.

${ }^{43}$ Ibidem, p. 279

${ }^{44}$ Ibidem, p. 283.

${ }^{45}$ Ibidem, p. 279.

${ }^{46}$ Decisão obtida no sitio do STJ: <http://www.stj.gov.br>. Acesso em: 03 mar. 2010. 
Outro exemplo da influência dos direitos sociais na interpretação e aplicação das normas jurídicas infraconstitucionais incidentes sobre as relações privadas vem ocorrendo em relação à Lei $n^{0}$ 8.009/90, que trata da impenhorabilidade do bem de família. A partir de uma interpretação ampliativa do conceito de entidade familiar, previsto no art. $1^{\circ}$ da norma, a jurisprudência vem estendendo a proteção legal para núcleos de pessoas não ligadas por laços de casamento ou consangüinidade, e até mesmo para devedores que vivam sozinhos em suas residências, diante da necessidade de tutela do direito fundamental à moradia. ${ }^{47}$ Nesse sentido, o acórdão proferido por unanimidade pela 6. ${ }^{a}$ Turma do STJ, no julgamento do Recurso Especial $n^{\circ} 182.223$, relatado pelo Min. Luiz Vicente Cernicchiaro, apreciado em 19 de agosto de 1999:

RESP. CIVIL - IMÓVEL - IMPENHORABILIDADE - A Lei 8.009/90, art. $1 .^{\circ}$, precisa ser interpretada consoante o sentido social do texto. Estabelece limitação à regra draconiana de o patrimônio do devedor responder por suas obrigações patrimoniais. O incentivo à casa própria busca proteger as pessoas, garantindo-lhes o lugar para morar. Família, no contexto, significa instituição social de pessoas que se agrupam, normalmente por laços de casamento, união estável ou descendência. Não se olvidem ainda os ascendentes. Seja o parentesco civil, ou natural. Compreende ainda a família substitutiva. Nessa linha, conservada a teologia da norma, o solteiro deve receber o mesmo tratamento. Também o celibatário é digno dessa proteção. E mais. Também o viúvo, ainda que seus descendentes hajam constituído outras famílias, e, como normalmente acontece, passem a residir em outras casas. Data venia, a Lei 8.009/90 não está dirigida a número de pessoas. Ao contrário - à pessoa. Solteira, casada, viúva, desquitada, divorciada, pouco importa. O sentido social da norma busca garantir um teto para cada pessoa. Só essa finalidade, data venia, põe sobre a mesa a exata extensão da lei. Caso contrário, sacrificar-se-á a interpretação teleológica para prevalecer a insuficiente interpretação literal. ${ }^{48}$

Em abril de 2005, no julgamento do Recurso Extraordinário n. 352.940/SP, o STF apreciou a constitucionalidade de dispositivo da Lei n. 8.245/91, que introduzira uma nova exceção à regra da impenhorabilidade do bem de família, estabelecida no art. $1^{\circ}$ da Lei $n^{\circ} 8.009 / 90$, já antes citada, relativa às dívidas decorrentes de fianças concedidas em contratos de locação. O STF, ao considerar que a impenhorabilidade do bem de família traduz instrumento de proteção ao direito à moradia, entendeu que a norma em questão não fora recepcionada pela EC n. 26/2000, que consagrou expressamente a moradia como direito fundamental, incluindo-a no elenco do art. $6^{\circ}$ da CF. O Min. Carlos Mário Velloso, relator do acórdão, empregou ainda o princípio da isonomia na sua argumentação, já que, segundo seu entendimento, estava presente no caso a mesma ratio subjacente ao instituto da impenhorabilidade, não se justificando assim o seu afastamento. Consta do acórdão:

\footnotetext{
${ }^{47}$ Veja-se, a propósito, SCHEREIBER, Anderson. Direito à moradia como fundamento para impenhorabilidade do imóvel residencial do devedor solteiro. In: RAMOS, Carmem Lucia Silveira, et al. Diálogos sobre Direito Civil: construindo uma racionalidade contemporânea. Rio de Janeiro: Renovar, 2002, p. 77-98.

${ }^{48}$ Decisão obtida no sitio do STJ: <http://www.stj.gov.br>. Acesso em: 03 mar. 2010.
} 
Isto quer dizer que, tendo em vista o princípio isonômico, o citado dispositivo - inciso VII do art. $3^{\circ}$, acrescentado pela Lei 8.245/91 -, não foi recebido pela EC 26, de 2000. Essa não-recepção mais se acentua diante do fato da EC 26, de 2000, ter estampado, expressamente, no art. $6^{\circ}$, o direito à moradia como direito fundamental de $2^{\mathrm{a}}$ geração, direito social. Ora, o bem de família - Lei 8.009/90, art. $1^{\circ}$ - encontra justificativa, foi dito atrás, no constituir o direito à moradia um direito fundamental que deve ser protegido e por isso mesmo encontra garantia na Constituição. Em síntese, o inciso VII do art. $3^{\circ}$ da Lei 8.009 de 1990, introduzido pela Lei 8.245, de 1991, não foi recebido pela CF, art. $6^{\circ}$, redação da EC $26 / 2000 .^{49}$

Outro caso envolvendo a dimensão negativa do direito à moradia foi decidido pela $9^{a}$ Câmara Cível do Tribunal de Justiça do Estado do Rio Grande do Sul, no Agravo de Instrumento n. 70003299401, julgado em 28 de novembro de 2001, e relatado pela Desembargadora Mara Larsen Chechi. Tratava-se de execução extrajudicial de dívida hipotecária que recaía sobre imóvel no qual o devedor tinha a sua residência. Ao apreciar a questão, decidiu o Tribunal:

SISTEMA FINANCEIRO HABITACIONAL E PROCESSUAL CIVIL - EXECUÇÃO EXTRAJUDICIAL - SITUAÇÃO - ANTECIPAÇÃO DE TUTELA - IMÓVEL HIPOTECADO - LITÍGIO ACERCA DO DÉBITO DIREITO À MORADIA - PROTEÇÃO - DIGNIDADE HUMANA INTERESSE PREVALENTE - A pendência de litígio acerca do débito de mútuo hipotecário torna controvertida a liquidez da dívida e a mora, conferindo verossimilhança ao alegado direito à suspensão da execução extrajudicial, para proteção da moradia, indispensável à operacionalização da garantia constitucional à dignidade da vida humana, que se sobrepõe a direitos meramente patrimoniais. ${ }^{50}$

Mais complexa, no entanto, é a possibilidade de extrair, de uma norma consagradora de direito social de caráter não trabalhista, algum direito subjetivo positivo a determinada prestação comissiva devida pelo particular, independentemente da existência de lei ordinária, ou de cláusula do Direito Privado suscetível de concretização judicial. Mas apesar das dificuldades, a jurisprudência brasileira registra alguns casos interessantes. Vale destacar, por exemplo, o acórdão proferido pelo Tribunal de Justiça do Rio de Janeiro, que reconheceu a eficácia direta do direito à saúde numa relação privada, impondo ao empregador um dever prestacional, ligado à sua relação jurídica com o trabalhador:

FUNCIONÁRIO CONTRATADO PELA CLT - PENA DE SUSPENSÃO
- ASSISTENCIA MÉDICO-HOSPITALAR - MEDIDA LIMINAR
CONCEDIDA - AGRAVO DE INSTRUMENTO - RECURSO DESPROVIDO
- Agravo. Concessão de liminar obrigando a empresa a prestar assistência
médica e hospitalar à empregada afastada da mesma por motivo de saúde.
A suspensão, pela empresa/empregadora, colocou em risco a vida da empregada.
Saúde é um direito social a todos garantido, como prevê o dispositivo do art. $6^{\circ}$,

${ }^{49}$ Decisão obtida no sitio do STF: <http://www.stf.gov.br>. Acesso em: 03 mar. 2010.

${ }^{50}$ Decisão obtida no sitio do TJRS: <http://www.tjrs.gov.br>. Acesso em: 10 nov. 2009. 
Somente para estabelecer um paralelo, vale destacar que na Espanha - um dos países que mais avançou na proteção dos direitos fundamentais nas relações privadas -, o Tribunal Constitucional, em sede de recurso de amparo, rejeitou a possibilidade de reconhecer, a partir da Constituição, um direito subjetivo à educação, invocável no âmbito das relações privadas. No caso, dois empregados do turno da noite de um hospital se insurgiram contra a mudança do seu horário de serviço, que prejudicaria cursarem a universidade no horário em que estavam matriculados. O Tribunal denegou o amparo alegando que não poderia obrigar um empregador a satisfazer a pretensão dos seus empregados à compatibilização do horário de trabalho com a frequiência a uma instituição de ensino, porque, do contrário, isso equivaleria a:

[...] desplazar sobre el empleador la carga prestacional del derecho a la educación, que sólo sobre los poderes públicos pesa, y hacer responsable a aquél del deber positivo de garantizar la efectividad del derecho fundamental a la educación en una imprevisible justificativa del incumplimiento por parte del trabajador de sus obligaciones laborales. ${ }^{52}$

Assim, quando a jurisprudência brasileira reconhece, em alguma medida, a vinculação direta dos particulares a direitos prestacionais, ela assume uma posição bastante avançada. Contudo, insiste-se na necessidade de estabelecimento de parâmetros ético-jurídicos para essa vinculação.

\section{A GARANTIA DO MÍNIMO EXISTENCIAL}

Na filosofia política contemporânea, existe relativo consenso (do qual estão excluídos apenas os pensadores ditos libertários) de que é papel do Estado assegurar as condições materiais mínimas de vida para as pessoas mais necessitadas. ${ }^{53}$ Entre os principais argumentos morais para justificar essa obrigação, dois são instrumentais e um não é. Os argumentos instrumentais são no sentido de que se trata de uma obrigação necessária: (i) para a garantia da liberdade real; ou (ii) para a proteção dos pressupostos da democracia. $\mathrm{O}$ argumento moral não-instrumental é o de que o atendimento das necessidades humanas essenciais constitui um fim em si mesmo e não um meio para obtenção de qualquer outra finalidade. ${ }^{54}$

$\mathrm{O}$ argumento da liberdade real tem muito prestígio dentre os adeptos do liberalismo igualitário, e foi defendido por filósofos como John Rawls, ${ }^{55}$ economistas

${ }^{51}$ Decisão obtida no sitio do TJRJ: <http://www.tjrj.gov.br>. Acesso em: 09 nov. 2009.

${ }^{52}$ BILBAO UBILLOS, 1997, op. cit., p. 837-839.

${ }^{53}$ Cf. ARANGO, 2005, op. cit., p. 238-296; BARCELLOS, Ana Paula de. O mínimo existencial e algumas fundamentações: John Rawls, Michael Walzer e Robert Alexy. In: TORRES, Ricardo Lobo (Org.). Legitimação dos direitos humanos. Rio de Janeiro: Renovar, 2007, p. 97-135.

54 SARMENTO, Daniel. A proteção judicial dos direitos sociais: alguns parâmetros ético-jurídicos. In: ARRUDA, Paula (Coord.). Direitos Humanos: questões em debate. Rio de Janeiro: Lumen Juris, 2009, p. 141-182, p. 164.

${ }^{55}$ Rawls, ao enunciar, em sua obra sobre a Teoria da Justiça, os princípios políticos que deveriam reger a 
como Amartya Sen $^{56}$ e juristas como Robert Alexy ${ }^{57}$ e Ricardo Lobo Torres. ${ }^{58}$ Para essa corrente de pensamento, a ideia fundamental é a de que sem a garantia de certas condições materiais básicas, esvazia-se a liberdade, pela impossibilidade do seu exercício. A liberdade, sob essa ótica, não se esgota na ausência de impedimentos externos à ação do agente, envolvendo também a possibilidade do seu exercício. E esta, por sua vez, demanda que sejam garantidas certas condições materiais mínimas para as pessoas carentes.

O argumento democrático baseia-se na ideia, defendida por pensadores como Jürgen Habermas $^{59}$ e por juristas como Friedrich Muller ${ }^{60}$, de que a democracia não se confunde com a vontade da maioria, exigindo a garantia de certos direitos que viabilizem a participação dos cidadãos nas decisões. Entre os direitos garantidos, é necessário que figure a satisfação das necessidades básicas dos que se encontram à margem da afluência material da sociedade, sem o que também restaria comprometida a sua capacidade real de participar das deliberações adotadas na sociedade.

Finalmente, o argumento moral não-instrumental é o de que o atendimento das necessidades materiais básicas da pessoa humana é uma exigência autônoma da justiça, que se impõe independentemente das suas conseqüências para a promoção de outros objetivos, como a garantia da liberdade ou mesmo a promoção da democracia.

estrutura básica de uma sociedade justa, atribuíra absoluta prioridade à proteção, igual para todos, das liberdades individuais básicas. Somente depois de assegurado plenamente este princípio de maximização das liberdades, passar-se-ia à aplicação do segundo princípio de justiça, que ele chamou de princípio da diferença, segundo o qual as desigualdades econômicas deveriam ser distribuídas de forma (a) a beneficiar as pessoas menos favorecidas, e (b) a manter sempre abertas oportunidades iguais para todos. Cf. RAWS, John. Uma teoria da justiça. São Paulo: Martins Fontes, 1997, p. 64. Essa prioridade absoluta conferida ao primeiro princípio foi alvo de severas críticas, no sentido de que poderia frustrar, na prática, o gozo das liberdades individuais básicas pelos mais pobres. Disso decorre, em obra posterior, revendo em parte sua teoria inicial, Rawls reconhecer que "o primeiro princípio, que trata dos direitos e liberdades básicos e iguais, pode facilmente ser precedido de um princípio lexicamente anterior, que prescreva a satisfação das necessidades básicas dos cidadãos, ao menos à medida que a satisfação dessas necessidades seja necessária para que os cidadãos entendam e tenham condições de exercer de forma fecunda esses direitos e liberdades”. Cf. RAWLS, John. O liberalismo político. São Paulo: Ática, 2000, p. 49.

56 Segundo Amartya Sen: “a condição de agente de cada um é inescapavelmente limitada pelas oportunidades sociais, políticas e econômicas de que dispomos. Existe uma acentuada complementaridade entre a condição de agente individual e as disposições sociais: é importante o reconhecimento simultâneo da centralidade da liberdade individual e da força das influências sociais sobre o grau e alcance da liberdade individual”. Cf. SEN, Amartya. Desenvolvimento como Liberdade. São Paulo: Companhia das Letras, 1999, p. 17.

${ }^{57}$ De acordo com Robert Alexy: “o enunciado da igualdade, que inclui a igualdade fática, pode, nos casos de mínimo existencial, fundamentar direitos definitivos concretos à criação de uma igualdade fática”. Cf. ALEXY, Robert. Teoria dos Direitos Fundamentais. São Paulo: Malheiros, 2008, p. 429.

${ }^{58}$ Nas palavras de Torres: "sem o mínimo necessário à existência cessa a possibilidade de sobrevivência do homem e desaparecem as condições iniciais de liberdade”. Cf. TORRES, Ricardo Lobo. O direito ao mínimo existencial. Rio de Janeiro: Renovar, 2009, p. 36.

${ }^{59}$ A teoria de Habermas sobre a relação entre direitos humanos e democracia é extremamente complexa, de forma que vale a pena consultar o próprio autor, em especial: HABERMAS, Jürgen. Direito e democracia: entre facticidade e validade. Rio de Janeiro: Tempo Brasileiro, vol. I, 1997, p. 160.

${ }^{60}$ MÜLLER, Friedrich. Que grau de exclusão social ainda pode ser tolerado por um sistema democrático? Revista da Procuradoria-Geral do Município de Porto Alegre, Edição Especial. Disponível no sítio: <http://www2.portoalegre.rs.gov.br>. Acesso em: 05 nov. 2009. 
O filósofo alemão Ernst Tugendhat ${ }^{61}$ é um dos seus defensores, assim como Paulo Gilberto Cogo Leivas ${ }^{62}$ e Daniel Sarmento, ${ }^{63}$ na doutrina jurídica brasileira.

É obvio que a garantia do mínimo existencial constitui também, em geral, um pressuposto fático seja para o gozo das liberdades individuais, seja para o exercício da cidadania política. Ainda que assim não fosse, uma compreensão correta da ideia de justiça teria de envolver a obrigação moral do Estado e da sociedade de combater o sofrimento e a miséria humana. Veja-se o exemplo, citado por Sarmento, de um indivíduo que padeça de deficiência mental severa e incurável e que esteja em situação de absoluta penúria material: “poucos discutirão que ele também faz jus à garantia do mínimo existencial, apesar de não fazer muito sentido falar desta garantia como um pressuposto para o exercício da sua liberdade ou do seu direito à participação política”. ${ }^{6}$

O direito ao mínimo existencial corresponde à garantia das condições indispensáveis para uma vida condigna. Ele ostenta tanto uma dimensão negativa, como uma positiva. Na sua dimensão negativa, o mínimo existencial atua como um limite, impedindo a prática de atos, pelo Estado e por particulares, que subtraiam do indivíduo as referidas condições materiais indispensáveis para uma vida digna. Já na sua dimensão positiva, ele envolve um conjunto essencial de direitos prestacionais. Não há, porém, a possibilidade de se estabelecer, de forma apriorística e acima de tudo de modo taxativo, um rol das prestações que compõem esse conjunto, o que não afasta a possibilidade de se inventariar todo um rol de conquistas já sedimentadas e que, em princípio e sem excluírem outras possibilidades, servem como uma espécie de roteiro a guiar o intérprete e, de modo geral, os órgãos vinculados à concretização da garantia do mínimo existencial. ${ }^{65}$

A ideia de um direito ao mínimo existencial surgiu em decisão do Tribunal Federal Administrativo alemão, proferida em 1953, incorporando-se, posteriormente, na jurisprudência da Corte Constitucional daquele Estado, a partir da conjugação dos princípios da dignidade da pessoa humana, da liberdade material e do Estado Social, consagrados na Lei Fundamental germânica. ${ }^{66}$ Ela tem recebido acolhida na jurisprudência constitucional de diversos outros países, como Portugal ${ }^{67}$ e Colômbia. ${ }^{68}$

${ }^{61}$ TUGENDHAT, Ernst. Lições sobre Ética. 4.ed. Petrópolis: Vozes, 1996, p. 386-389.

${ }^{62}$ LEIVAS, Paulo Gilberto Cogo. Teoria dos Direitos Fundamentais Sociais. Porto Alegre: Livraria do Advogado, 2006, p. 123-139.

${ }^{63}$ SARMENTO, 2009, op. cit., p. 165.

${ }^{64}$ Ibidem, p. 166.

${ }^{65}$ Nesse sentido, Barcellos sustenta que: “uma proposta de concretização do mínimo existencial, tendo em conta a ordem constitucional brasileira, deverá incluir os direitos à educação fundamental, à saúde básica, à assistência no caso de necessidade e ao acesso à justiça”. Cf. BARCELLOS, op. cit., p. 305.

${ }^{66}$ SARLET, 2006, op. cit., p. 564-565.

${ }^{67}$ Nesse sentido, o Acórdão n. 509/02, proferido em 22 de novembro de 2002, pelo Tribunal Constitucional Português, deduzindo do princípio da dignidade da pessoa humana "uma obrigação, juridicamente exigível, de manutenção objectiva das prestações materiais destinadas a assegurar a existência condigna". Cf. NOVAIS, Jorge Reis. Os Princípios Constitucionais Estruturantes da República Portuguesa. Coimbra; Coimbra, 2004, p. 67-100.

${ }^{68}$ ARANGO, Rodolfo; LEMAITRE, Julieta (Directores). Jurisprudencia constitucional sobre el derecho al mínimo vital. Estudios Ocasionales CIJUS, Universidad de los Andes, Facultad de Derecho, Bogotá, 2002, p. 07-74. 
E aqui, no Brasil, o conceito, introduzido na doutrina pela obra de Ricardo Lobo Torres, ${ }^{69}$ também já foi invocado em decisões do STF. ${ }^{70}$

Contudo, convém frisar que a inserção ou não de determinada prestação no âmbito do mínimo existencial não pode ser realizada in abstracto, ignorando a condição específica do suposto titular do direito. Por exemplo, o fornecimento de um medicamento certamente integrará o mínimo existencial para aquele indivíduo que dele necessite para sobreviver, e não possua os recursos suficientes para adquiri-lo. Porém, o mesmo medicamento estará fora do mínimo existencial para um paciente que, padecendo da mesma moléstia, tenha os meios próprios para comprá-lo, sem prejuízo da sua subsistência digna.

A solução, como bem referiu Sarmento, é saber até que ponto a necessidade invocada é vital para o suposto titular do direito, aferindo quais seriam as consequiências, para o autor da demanda, se lhe fosse negada a pretensão. ${ }^{71}$ Isso, todavia, não implica em confundir o mínimo existencial com o que se tem chamado de mínimo vital, de vez que este último diz com a garantia da vida humana, sem necessariamente abranger as condições para uma sobrevivência em condições dignas. Nesse sentido, Sarlet observa: "Não deixar alguém sucumbir à fome certamente é o primeiro passo em termos de garantia de um mínimo existencial, mas não é - e muitas vezes não o é sequer de longe - o suficiente”. ${ }^{72}$ Tal constatação, no entanto, nunca impediu que se sustentasse que a obrigação, mesmo do Estado - em termos de direitos subjetivos a prestações -, estaria limitada à garantia do mínimo vital, posição esta, aliás, enfaticamente refutada por Sarmento, ao destacar, entre outros aspectos, a direta fundamentação do mínimo existencial no princípio da dignidade da pessoa humana. ${ }^{73}$

Por outro lado, não parece correta a tese de que o papel do Judiciário em matéria de proteção aos direitos sociais tenha sempre de se limitar à garantia do mínimo existencial. ${ }^{74}$ Se em relação a todos os demais direitos fundamentais persegue-se a

${ }^{69}$ O primeiro artigo de Ricardo Lobo Torres a versar sobre esta matéria é de 1989. Cf. TORRES, Ricardo Lobo. O mínimo existencial e os direitos fundamentais. Revista de Direito Administrativo, Rio de Janeiro: Renovar, n. 177, jul/1989, p. 29-48.

${ }^{70}$ Nesse sentido, veja-se o acórdão proferido pela $1^{\text {a }}$ Turma do STJ no REsp. n. 430.526/SP, julgado em $1^{\circ}$.10.2002, e relatado pelo Min. Luiz Fux, em que se entendeu irrelevante para a decisão de um caso em que um paciente demandava o fornecimento de medicamento não contemplado na lista do SUS, o fato de se tratar de um Delegado de Polícia, com rendimentos muito superiores à média nacional. Decisão obtida no sitio do STF: <http://www.stf.gov.br>. Acesso em: 03 mar. 2010.

${ }^{71}$ SARMENTO, 2009, op. cit., p. 167-168.

72 SARLET, 2006, op. cit., p. 567.

${ }^{73}$ SARMENTO, 2009, op. cit., p. 166.

${ }^{74}$ Essa é a posição defendida por Ricardo Lobo Torres: "Parece-nos que a jusfundamentalidade dos direitos sociais se reduz ao mínimo existencial, em seu duplo aspecto de proteção negativa contra a incidência de tributos sobre os direitos sociais mínimos de todas as pessoas e de proteção positiva consubstanciada na entrega de prestações estatais materiais em favor dos pobres. Os direitos sociais máximos devem ser obtidos na via do exercício da cidadania reivindicatória e da prática orçamentária, a partir do processo democrático. Esse é o caminho que leva à superação da tese do primado dos direitos sociais prestacionais (ou direitos a prestações positivas do Estado, ou direitos de crédito - droit créance - ou Teilhaberechte) sobre os direitos da liberdade, que inviabilizou o Estado Social de Direito, e ao desfazimento da confusão entre direitos fundamentais e direitos sociais, que não permite a eficácia destes últimos sequer na sua dimensão mínima. Cf. TORRES, 2009, op. cit., p. 41. 
máxima efetividade, naquilo que seja fática e juridicamente possível, em matéria de direitos sociais por que se contentar com o mínimo? O ponto a que pode chegar o Judiciário depende de uma ponderação de interesses a ser feita em cada caso, na qual, de um lado, figure o direito social em jogo, e, do outro, os princípios concorrentes, como o da autonomia privada, da livre iniciativa, de propriedade etc.

Neste modelo, considera-se que o mínimo existencial constitui elemento importante, pois, quanto mais essencial a necessidade material em jogo, maior será o peso atribuído ao direito social no processo ponderativo. Prestações situadas fora do mínimo existencial têm, portanto, uma chance menor de êxito, já que quando elas estiverem em questão o direito social comparecerá à ponderação com peso reduzido. Ainda assim persiste a possibilidade de adjudicação judicial de direitos sociais mesmo naquilo que extrapolar ao mínimo existencial, em razão da força normativa que tais direitos possuem.

Além de todos os argumentos acima expendidos, especialmente no que diz respeito à incidência da dimensão prestacional dos direitos sociais nas relações privadas, ainda há um dado sistêmico importante, que deve ser devidamente sopesado.

\section{O PRINCÍPIO DA SOLIDARIEDADE}

Na Constituição de 1988, o princípio da solidariedade está formulado expressamente, como um dos objetivos fundamentais da República brasileira: “art. $3^{\circ}$. Constituem objetivos fundamentais da República Federativa do Brasil: I - construir uma sociedade livre, justa e solidária”. Diz-se, então, que a solidariedade é uma normaconstitucional-objetivo no sentido de norma-constitucional-princípio. Em suma, é um princípio constitucional. ${ }^{75}$

Mas, a exemplo de outros conceitos jurídicos, como liberdade, igualdade e dignidade da pessoa humana, a solidariedade também é, originariamente, um conceito moral. A ideia de solidariedade pode ser encontrada na Antiguidade clássica, próxima da noção de amizade (filia). Na Idade Média, ela alcança uma dimensão religiosa com o cristianismo, especialmente pela noção de caridade e beneficência. Porém, na Modernidade, a solidariedade se laiciza, enriquecida pelas ideias dos socialistas utópicos, como Saint-Simon (1760-1825), Charles Fourier (1772-1837) e Robert Owen (1771-1858), e as contribuições dos socialistas de matriz marxista. ${ }^{76}$

Apesar do lema Liberdade, Igualdade e Fraternidade da Revolução Francesa, o constitucionalismo liberal não foi sensível à noção de fraternidade e, por conseqüência, de solidariedade. ${ }^{77}$ A ideia de solidariedade somente se manifestou na fase do

\footnotetext{
${ }^{75}$ STEINMETZ, op. cit., p. 118.

${ }^{76}$ Sobre o itinerário histórico da ideia de solidariedade, cf. PECES-BARBA MARTINEZ, Gregorio. Curso de derechos fundamentales: teoría general. Madrid: Universidad Carlos III, 1999, p. 263-275. Cf. tb. FARIAS, José Fernando de Castro. A origem do direito de solidariedade. Rio de Janeiro: Renovar, 1998.

${ }^{77}$ Nesse sentido, a análise de Maria Celina Moraes: “A lógica assistencialista, por isso mesmo, perdurou por longo tempo e, quando não pôde mais ser reconduzida às formas originárias de caridade e beneficência, foi atribuída ao Estado, através de um conjunto de normas pelas quais este deveria prover as necessidades do trabalhador, fazendo-o beneficiário da previdência social, quando um acidente, doença ou a idade interrompessem sua atividade remunerada”. Cf. MORAES, Maria Celina Bodin. O princípio da solidariedade. In: PEIXINHO, Manoel Messias; GUERRA, Isabella Franco; NASCIMENTO FILHO, Firly. (Orgs.). Os princípios da Constituição de 1988. 2.ed. rev. e ampl. Rio de Janeiro: Lumen Juris, 2006, p. 157-176, p. 165.
} 
constitucionalismo social, com a incorporação aos documentos constitucionais de preceitos definidores de direitos fundamentais sociais. As referências históricas iniciais são a Constituição Mexicana de 1917 e a Constituição de Weimar de 1919. Assim, a partir da década de 30 do século XX, com a formação e o desenvolvimento do Estado Social (Welfare State), sobretudo na Europa, a solidariedade consolida-se como valor e diretriz constitucional. E a ideia de solidariedade do constitucionalismo social é uma contrapartida ao individualismo liberal-burguês, tão bem representado no constitucionalismo dos séculos XVIII e XIX. ${ }^{78}$

Esse dado histórico - a conexão solidariedade/direitos fundamentais sociais/ Estado Social - é relevante para determinar o sentido (conteúdo) do princípio constitucional da solidariedade. Do ponto de vista do objeto ou da proteção, o princípio constitucional da solidariedade refere-se ao bem-estar das pessoas e grupos, ao atendimento das necessidades básicas para uma vida digna e ao mínimo existencial. Do ângulo dos titulares, figuram todas as pessoas titulares de direitos fundamentais sociais, sobretudo as que se encontram econômica, social e culturalmente em posição ou situação de desvantagem (ou necessidade, no caso do mínimo existencial). Do ângulo dos destinatários, o Estado é o destinatário em primeiro plano. Como bem enunciou Steinmetz, o princípio da solidariedade exige do Estado: (i) a garantia efetiva dos direitos fundamentais sociais; (ii) a promoção do bem-estar social geral das pessoas (e.g., criação de uma rede de proteção social); e (iii) a criação de mecanismos e incentivos de cooperação social e de ajuda mútua entre os particulares, isto é, o fomento da solidariedade nas relações horizontais. ${ }^{79}$

Mas o Estado não é o único destinatário do princípio constitucional da solidariedade. Ao lado do dever primário do Estado, de garantir os direitos sociais, é possível visualizar um dever secundário da sociedade de assegurá-los: $\left(1^{\circ}\right)$ porque as relações privadas, que se desenvolvem sob o pálio da Constituição, não estão isentas dos valores constitucionais, que impõem sua conformação aos parâmetros materiais de justiça, dentre os quais desponta a ideia de solidariedade; e $\left(2^{\circ}\right)$ porque, diante da decantada crise de financiamento do Welfare State, que o impede de atender a todas as demandas sociais relevantes, é importante encontrar outros co-responsáveis que sem exclusão da obrigação primária do Estado - possam contribuir para amenizar o dramático quadro de miséria hoje existente, assumindo tarefas relacionadas à garantia de condições materiais mínimas para os excluídos, agora não mais por caridade ou filantropia, mas no cumprimento de deveres juridicamente exigíveis. ${ }^{80}$

A noção de solidariedade articula-se, assim, com a de responsabilidade social. E o dever de responsabilidade social, certamente, não é de exclusividade do Estado, embora sobre ele incida primariamente. Ao menos na Constituição Federal, não está autorizada nem é permitida a irresponsabilidade social dos particulares. São significativos os arts. 205, 221, caput, e IV, e 230. No art. 205, enuncia-se que

\footnotetext{
${ }^{78}$ Naquela época, era o Código Civil que fazia as vezes da Constituição, estabelecendo as regras do jogo e propiciando, através delas, plena liberdade àquele que representava o valor fundamental do pensamento liberal: o indivíduo livre e igual, submetido apenas à sua própria vontade. Cf. Ibidem, p. 162.

${ }^{79}$ STEINMETZ, op. cit., p.119-120.

${ }^{80}$ SARMENTO, 2008, op. cit., p. 295.
} 
“a educação, direito de todos e dever do Estado e da família, será promovida e incentivada com a colaboração da sociedade, visando o pleno desenvolvimento da pessoa [...]”. Assim, os particulares (família e sociedade) também têm responsabilidade no desenvolvimento da pessoa por meio do direito à educação. No art. 221, caput, e IV, que "a produção e a programação das emissoras de rádio e televisão atenderão aos seguintes princípios: [...] IV- respeito aos valores éticos e sociais da família”. Ora, é notório que, no Brasil, as emissoras de rádio e televisão, em sua quase totalidade, são de propriedade de particulares. Portanto, os principais destinatários dos dispositivos que ordenam o respeito aos valores éticos e sociais da pessoa e da família são os particulares. Por fim, no art. 230, prescreve-se que "a família, a sociedade e o Estado têm o dever de amparar as pessoas idosas, assegurando sua participação na comunidade, defendendo sua dignidade e bem-estar e garantindo-lhes o direito à vida”. Logo, a família e a sociedade têm deveres de defesa e de promoção da dignidade, do bem-estar e do direito à vida de outrem (no caso, dos idosos). ${ }^{81}$ É, pois, nesse sentido que se justifica a produção legislativa que, por exemplo, garante a gratuidade dos transportes de massa para idosos e deficientes de baixa renda, impõe regras para os reajustes dos planos de saúde em favor da pessoa idosa, obriga os bancos privados a destinarem uma parcela dos recursos que captarem a programas de financiamento de habitação popular etc.

Por último, para fechar este tópico, convém frisar que, embora o princípio da solidariedade, por si só, não seja suficiente para fundamentar uma vinculação dos particulares à dimensão prestacional dos direitos sociais (à vista do caráter secundário da obrigação da sociedade), há, todavia, razões suficientes para invocá-lo e qualificá-lo como um argumento adicional de reforço.

\section{CONCLUSÃO}

A constitucionalização do direito civil, entendida como inserção constitucional dos fundamentos de validade das relações civis, é mais do que um critério hermenêutico formal. Ela constitui a etapa mais importante do processo de transformação, ou de mudanças de paradigmas, pelo qual passou o direito civil nos dois últimos séculos. O conteúdo, a natureza, as finalidades dos institutos básicos do direito civil, nomeadamente a família, a propriedade e o contrato, não são mais os mesmos que vieram do individualismo jurídico e da ideologia liberal oitocentista. A afetividade desponta como valor essencial da família; a função social, como conteúdo e não apenas limite, da propriedade, nas dimensões variadas; o princípio da igualdade material e a tutela do contratante mais fraco, no contrato.

Nesse contexto, afigura-se mais adequada a tese da aplicabilidade em princípio direta dos direitos fundamentais sociais às relações privadas. Na ponderação a ser empreendida, como na ponderação em geral, devem ser levados em conta os elementos do caso concreto. Para esta específica ponderação entre autonomia da vontade versus direito fundamental social em questão, merecem relevo os seguintes critérios: (i) a igualdade ou desigualdade material entre as partes (e.g., considerar abusiva a cláusula que limita no tempo a internação do segurado, com base na desvantagem exagerada

${ }^{81}$ STEINMETZ, op. cit., p. 121. 
do consumidor); (ii) a relevância da prestação social em discussão (e.g., estender a proteção do bem de família para núcleos de pessoas não ligadas por laços de casamento ou consangüinidade, e até mesmo para devedores que vivam sozinhos em suas residências); (iii) a sobreposição da proteção da dignidade da pessoa humana (do mínimo existencial) a direitos meramente patrimoniais (e.g., suspender execução extrajudicial de dívida hipotecária que recaía sobre imóvel no qual o devedor tinha a sua moradia); (iv) a co-responsabilidade dos particulares com relação à garantia do direito em questão (e.g., obrigar a empresa a prestar assistência médica e hospitalar à empregada afastada da mesma por motivo de saúde).

\section{REFERÊNCIAS}

ALEXY, Robert. Teoria dos Direitos Fundamentais. São Paulo: Malheiros, 2008.

ARANGO, Rodolfo. El concepto de derechos sociales fundamentales. Bogotá: Legis, 2005.

; LEMAITRE, Julieta (Directores). Jurisprudencia constitucional sobre el derecho al mínimo vital. Estudios Ocasionales CIJUS, Universidad de los Andes, Facultad de Derecho, Bogotá, 2002, p. 07-74.

ASÍS, Rafael de. Las paradojas de los derechos fundamentales como limites al poder. Madrid: Dykinson, 2000.

BARCELLOS, Ana Paula de. A eficácia jurídica dos princípios constitucionais: o princípio da dignidade da pessoa humana. Rio de Janeiro: Renovar, 2002.

O mínimo existencial e algumas fundamentações: John Rawls, Michael Walzer e Robert Alexy. In: TORRES, Ricardo Lobo (Org.). Legitimação dos Direitos Humanos. Rio de Janeiro: Renovar, 2007, p. 97-135.

BARROSO, Luís Roberto. A constitucionalização do direito civil e o direito civil. In: TEPEDINO, Gustavo (org.). Direito civil contemporâneo: novos problemas à luz da legalidade constitucional: anais do Congresso Internacional de Direito Civil-Constitucional da Cidade do Rio de Janeiro. São Paulo: Atlas, 2008, p. 238-61.

BILBAO UBILLOS, Juan María. ¿En qué medida vinculan a los particulares los derechos fundamentales? In: SARLET, Ingo Wolfgang (org.). Constituição, Direitos Fundamentais e Direito Privado. 2.ed. rev. e ampl. Porto Alegre: Livraria do Advogado, 2006b, p. 301-339.

La eficacia de los derechos fundamentales frente a particulares: análisis de la jurisprudencia del Tribunal Constitucional. Madrid: Centro de Estudios Políticos y Constitucionales, 1997.

CANÇADO TRINDADE, Antônio Augusto. Elementos fundamentais da evolução da proteção internacional dos direitos humanos. Arquivos do Ministério da Justiça, v. 177, 1991. p. 39-60.

CANOTILHO, José Joaquim Gomes. Direito Constitucional e Teoria da Constituição. 4. ed. Coimbra: Almedina, 2000.

CONSTANT, Benjamin. De la liberté des anciens compare a celle des modernes, Paris, 1819. Disponível no sítio: <http://www.panarchy.org/constant/liberte.1819.html>. Acesso em: 22 set. 2010.

FACHIN, Luiz Edson; RUZYK, Carlos Eduardo Pianovski. Um projeto de Código Civil na contramão da Constituição. Revista Trimestral de Direito Civil, Rio de Janeiro, v. 1, n. 4, 2000, p. 243-264.

FARIAS, José Fernando de Castro. A Origem do Direito de Solidariedade. Rio de Janeiro: Renovar, 1998. 
HABERMAS, Jürgen. Direito e democracia: entre facticidade e validade. vol. I. Rio de Janeiro: Tempo Brasileiro, 1997.

HESSE, Konrad. Derecho constitucional y derecho privado. Madrid: Civitas, 2001.

Escritos de derecho constitucional. 2. ed. Madrid: Centro de Estudios Políticos y Constitucionales, 1992.

LAFER, Celso. A reconstrução dos direitos humanos: um diálogo com o pensamento de Hannah Arendt. São Paulo: Companhia das Letras, c1988.

LEIVAS, Paulo Gilberto Cogo. Teoria dos Direitos Fundamentais Sociais. Porto Alegre: Livraria do Advogado, 2006.

LÔBO, Paulo Luiz Netto. Constitucionalização do direito civil. Revista de Informação Legislativa, Brasília: a. 36, n. 141, jan./mar, 1999. p. 99-109.

MENDES, Gilmar Ferreira. Direitos fundamentais e controle de constitucionalidade: estudos de direito constitucional. 2. ed. rev. e ampl. São Paulo: Celso Bastos, 1999.

MONTEIRO, António Pinto; NEUNER, Jörg; SARLET, Ingo Wolfgang (orgs.). Direitos fundamentais e direito privado: uma perspectiva de direito comparado. Coimbra: Almedina, setembro 2007.

MORAES, Maria Celina Bodin de. Conceito de dignidade humana: substrato axiológico e conteúdo normativo. In: SARLET, Ingo Wolfgang (org.). Constituição, Direitos Fundamentais e Direito Privado. 2. ed. rev. e ampl. Porto Alegre: Livraria do Advogado, 2006b, p. 107-149.

O princípio da solidariedade. In: PEIXINHO, Manoel Messias; GUERRA, Isabella Franco; NASCIMENTO FILHO, Firly. (Organizadores). Os princípios da Constituição de 1988. 2. ed. rev. e ampl. Rio de Janeiro: Lumen Juris, 2006, p. 157-176.

MÜLLER, Friedrich. Que grau de exclusão social ainda pode ser tolerado por um sistema democrático? Revista da Procuradoria-Geral do Município de Porto Alegre, Edição Especial. Disponível no sítio: <http://www2.portoalegre.rs.gov.br>. Acesso em: 05 nov. 2009.

NOVAIS, Jorge Reis. Os Princípios Constitucionais Estruturantes da República Portuguesa. Coimbra; Coimbra, 2004.

OTTO, Ignacio de. Derecho constitucional: sistema de fuentes. Barcelona: Ariel, 1999.

PECES-BARBA MARTINEZ, Gregorio. Curso de derechos fundamentales: teoría general. Madrid: Universidad Carlos III, 1999.

PEREIRA, Jane Reis Gonçalves. Interpretação Constitucional e Direitos Fundamentais. Rio de Janeiro: Renovar, 2006.

PERLINGIERI, Pietro. O Direito Civil na Legalidade Constitucional. Rio de Janeiro: Renovar, 2008.

Perfis do direito civil: introdução ao direito civil constitucional. Rio de Janeiro: Renovar, 1997.

QUADRA-SALCEDO, Tomás. El recurso de amparo y los derechos fundamentales en las relaciones entre particulares. Madrid: Civitas, 1981.

RAWLS, John. O Liberalismo Político. São Paulo: Ática, 2000.

SARLET, Ingo Wolfgang. Algumas considerações em torno do conteúdo, eficácia e efetividade do direito à saúde na Constituição de1988. Revista Interesse Público, São Paulo: v. 3, n. 12, out./dez. 2001. p. 91-107. 
Direitos fundamentais e direito privado: algumas considerações em torno da vinculação dos particulares aos direitos fundamentais. In: SARLET, Ingo Wolfgang (Org.). A Constituição concretizada: construindo pontes com o público e o privado. Porto Alegre: Livraria do Advogado, 2000.

Direitos fundamentais sociais, "mínimo existencial” e direito privado: breves notas sobre alguns aspectos da possível eficácia dos direitos sociais nas relações entre particulares. In: SARMENTO, Daniel; GALDINO, Flávio (Organizadores). Direitos fundamentais: estudos em homenagem ao Professor Ricardo Lobo Torres. Rio de Janeiro: Renovar, 2006a, p. 551-602.

O direito fundamental à moradia na Constituição: algumas anotações a respeito de seu contexto, conteúdo e possível eficácia. In: MELLO, Celso D. de Albuquerque; TORRES, Ricardo Lobo (Diretores). Arquivos de Direitos Humanos. Rio de Janeiro: Renovar, v. 04, 2002, p. 63-115. SARMENTO, Daniel. A ponderação de interesses na Constituição Federal. Rio de Janeiro: Lumen Juris, 2003.

A proteção judicial dos direitos sociais: alguns parâmetros ético-jurídicos. In: ARRUDA, Paula (Coord.). Direitos Humanos: questões em debate. Rio de Janeiro: Lumen Juris, 2009, p. 141-182.

Direitos Fundamentais e Relações Privadas. 2. ed. Rio de Janeiro: Lumen Juris, 2008.

SCHEREIBER, Anderson. Direito à moradia como fundamento para impenhorabilidade do imóvel residencial do devedor solteiro. In: RAMOS, Carmem Lucia Silveira, et al. Diálogos sobre Direito Civil: construindo uma racionalidade contemporânea. Rio de Janeiro: Renovar, 2002.

SEN, Amartya. Desenvolvimento como Liberdade. São Paulo: Companhia das Letras, 1999.

STEINMETZ, Wilson. A Vinculação dos Particulares a Direitos Fundamentais. São Paulo: Malheiros, 2004.

TEPEDINO, Gustavo (coord.). Problemas de Direito Civil-Constitucional. Rio de Janeiro: Renovar, 2000.

Temas de Direito Civil. Rio de Janeiro: Renovar, 1999.

TORRES, Ricardo Lobo. O Direito ao Mínimo Existencial. Rio de Janeiro: Renovar, 2009.

O mínimo existencial e os direitos fundamentais. Revista de Direito Administrativo, Rio de Janeiro: Renovar, n. 177, jul. 1989, p. 29-48.

TUGENDHAT, Ernst. Lições sobre Ética. 4. ed. Petrópolis: Vozes, 1996. 